\title{
Multi-local living employees in Stuttgart and Milan. An analysis of their employer support for the spatial-temporal organisation of their living arrangements
}

\author{
Lisa Garde (1) \\ Received: 14 January 2021 - Accepted: 28 July 2021 - Published online: 17 August 2021
}

\begin{abstract}
With work-related living in several places - also known as multi-local living - on the rise due to flexible working and living environments, employers are increasingly challenged to support multi-local living arrangements in order to recruit and retain qualified employees nationwide. This paper presents the first results of an analysis conducted in the cities of Stuttgart in Germany and Milan in Italy. With the help of semi-structured problem-oriented interviews with multi-local employees in knowledge-based sectors, their requirements and the benefits they currently receive from their employers in support of their living arrangements are examined. The results show, among other things, that in both cities certain types of companies are more open to these living arrangements. However, few employers were found to have official policies for dealing with multi-locality. Furthermore, it is shown that different types of multi-local employees require different support. The paper also discusses interactions between workrelated multi-locality and spatial development.
\end{abstract}

Keywords: Multi-local living - support requirements employers - spatial development - Stuttgart - Milan

$\triangle$ Lisa Garde, ILS - Institut für Landes- und Stadtentwicklungsforschung, Brüderweg 22-24, 44135 Dortmund, Germany lisa.garde@ils-forschung.de

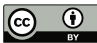
( 2021 Garde; licensee oekom verlag. This Open Access article is published under a Creative Commons Attribution 4.0 International License.

\section{Multilokal wohnende Erwerbstätige in Stuttgart und Mailand und ihre Unterstützung durch die Arbeitgeber - eine Analyse}

\section{Zusammenfassung}

Das berufsbedingte Wohnen an mehreren Orten, auch multilokales Wohnen genannt, nimmt aufgrund von flexibilisierten Arbeits- und Lebenswelten immer weiter zu. Um qualifizierte Erwerbstätige überregional zu rekrutieren und zu halten, sind Arbeitgeber besonders gefordert, multilokale Lebensweisen zu unterstützen. Dieser Beitrag stellt erste Ergebnisse einer in Stuttgart und Mailand (Italien) durchgeführten Analyse vor. Mithilfe von teilstrukturierten, problemorientierten Interviews wurden die Anforderungen von multilokal wohnenden Beschäftigten in wissensbasierten Branchen sowie die tatsächlich erhaltenen Unterstützungsleistungen ihrer Arbeitgeber bezüglich ihrer Wohnarrangements untersucht. Die Ergebnisse zeigen unter anderem, dass in beiden Städten bestimmte Unternehmenstypen offener gegenüber diesen Lebensweisen sind. Dennoch lassen sich kaum Arbeitgeber finden, die offizielle Strategien zum Umgang mit multilokalen Wohnarrangements haben. Darüber hinaus zeigt sich, dass unterschiedliche Typen von multilokal lebenden Mitarbeitern unterschiedliche Unterstützung brauchen. Der Beitrag diskutiert auch Wechselwirkungen zwischen berufsbedingter Multilokalität und Raumentwicklung.

Schlüsselwörter: Multilokales Wohnen Unterstützungsbedarf - Arbeitgeber - Raumentwicklung Stuttgart - Mailand 


\section{Introduction}

Many developed countries are shaped by growing workrelated mobility (Limmer/Collet/Ruppenthal 2010: 15) and multi-local living where everyday life takes place in and between two or more residences (Hilti 2013: 19). Indeed, living in more than one place for work-related reasons is not a new feature of late-modern societies. It has long been practiced by, for example, seasonal workers or merchants (Duchêne-Lacroix/Ködel 2020: 136). However, the deregulation and flexibilisation of labour markets and work organisation are increasing (Williams/Bradley/Devadason et al. 2013), leading to a rise in the quantitative importance of multi-local living arrangements (Lück/Ruppenthal 2010: 45). The phenomenon has also changed qualitatively, now covering many different occupational groups, especially in knowledge-based sectors (Bauder 2015: 85). ${ }^{1}$

From a spatial point of view, many regions are shaped by these living arrangements. Older industrial or structurally weak rural regions are tending to shrink due to demographic change and path dependencies, with people deciding to leave these areas (temporarily) to work in other regions (Christopherson/Michie/Tyler 2010: 6). In contrast, major metropolitan regions hosting international companies are profiting from the competition for resources and talents (Zenker/Eggers/Farsky 2013: 137). Booming regions in countries like Germany are suffering from skills shortages and mismatches in specific sectors such as engineering or information technologies (IT). As a result, employers are increasingly forced to recruit not just regionally, but also nationally or even internationally (Plöger 2020: 1741). This leads to more employees deciding to live a multi-local life and thus to spatial effects like higher traffic volumes and land consumption (ARL 2016: 16).

Due to changing forms of work organisation such as job flexibility and mobility requirements on the one hand and the competition for talents on the other, employers are increasingly called upon to contribute to reconciling their employees' work and private lives. It can be assumed that employees with more than one residence have specific support needs for their everyday lives with regard to such topics as housing, commuting between the residences and spacetime work arrangements. Employers need to support these employees if they want to attract them and avoid (further) skills shortages and mismatches. Moreover, the ability of

\footnotetext{
${ }^{1}$ By knowledge-based sectors we mean those with high-qualified employees using high-tech equipment: knowledge-intensive services like research and development or financial services as well as research-intensive industries like aerospace or mechanical engineering (Gehrke/Rammer/Frietsch et al. 2010: 11).
}

employers to attract and retain highly qualified employees is a sine qua non for strengthening the knowledge intensity of regional economies (Zenker/Eggers/Farsky 2013: 138).

International research is increasingly concerned with multi-local living. However, so far there has not been any in-depth examination of whether employers are aware of the growing number of such living arrangements and of how they can support them. The aim of this paper is to provide important insights into employees' perceptions of employer practices regarding such arrangements. The research questions are: (1) To what extent do multi-local employees in knowledge-based sectors demand and receive employer support for their living arrangements and how does this support influence the spatial development of cities and regions? (2) To what extent do different types of multi-local employees have specific support needs for their living arrangements? (3) How do employees cope when their employers do not accept their living situations? The paper draws on two samples of multi-local employees in knowledge-based jobs in two metropolitan cities - one in Germany, the other in Italy - to gain insights into similarities between the support demanded and received by employees in different spatial contexts. Studying two cities is intended "to separate patterns that are more general and isolate regularities from the context-laden environment" (Mills/van de Bunt/de Bruijn 2006: 621).

The study analyses employer approaches to multi-local living from an employee point of view, using semi-structured problem-oriented interviews with employees who live and work within either of the two metropolitan cities and have a further residence outside the region. In the spatialtemporal organisation of their everyday lives, which we assume can be influenced by employer policies, multi-local employees constantly establish new spaces for e.g. working or living, not in terms of territorial borders or "container space' but in terms of socially constructed space (Löw 2001: 270).

This introduction is followed by a section on the current state of research on work-related multi-locality and employer practices (Section 2). The paper goes on to introduce the methods and data basis (Section 3), before presenting empirical results focused on multi-local employees' specific support needs, their perceptions of employer practices and the spatial consequences for cities and regions. It also analyses employee strategies when employers show no acceptance of their living situations (Section 4). The conclusion discusses the findings and presents further research topics (Section 5). 


\section{State of research}

\subsection{Work-related multi-local living}

The reasons for living in more than one place are heterogeneous. In addition to work-related motives, the literature differentiates between family-, leisure- and partnership-related reasons. Several research disciplines deal with workrelated multi-local living. Migration and mobility research looks at the topic both overall (Kaufmann 2002; Elliott/ Urry 2010; Brickell/Datta 2011) and with a focus on specific sectors like the creative industry (Sheller/Urry 2006; Hansen/Niedomysl 2009; Nadler 2014) or knowledge-based industries (Bauder 2015; Petzold/Hilti 2015; Strambach/ Kohl 2015; Tippel/Plöger/Becker 2017; Ojala/Pyöriä 2018; Plöger 2020). Housing, household and family research investigates residential location decisions and housing needs (Reuschke 2010; Kaltenbach 2020) as well as the consequences for partnerships and families (Asendorpf 2008; Schier 2009; Montanari 2016).

Moreover, different types of multi-local households are examined (Weiske/Petzold/Zierold 2009; Hilti 2013; Dittrich-Wesbuer/Kramer 2014). Hesse and Scheiner (2007: 145-147) identified six space-related types of multi-local living. The first type refers to shuttles, i.e. people who have a secondary residence near their workplace. The second relates to transmigrants whose main and secondary residences are located in different countries. Third, couples with two independent households in the same city or further apart are described as Living-Apart-Together. The fourth type covers people with second homes used as retirement or holiday homes. The fifth refers to frequent movers, people who relocate the whole household for job-related motives, while the last type refers to children and adolescents commuting between divorced parents.

This paper focuses on work-related multi-local living against the background of the growth of this phenomenon in developed countries. Living in several places can be a reaction to flexible employment conditions (Weiske/Petzold/ Zierold 2009: 67). Job insecurity occurs due to longer probationary periods and the increase of project-based and fixed-term jobs (Boltanski/Chiapello 2007: 224-229; Destatis 2019: 364). As a result, employees change their jobs several times in the course of their working careers, not just to move up the career ladder but also just to remain in work (Rüger/Ruppenthal 2010: 75). If there is a lack of suitable jobs near home, having a further residence in another region or country can be a strategy to expand job opportunities (Weichhart 2015: 388). At the same time, multi-local living can help people stay connected to their home cities, continuing to benefit from social contacts, certain infrastructures or environmental conditions as well as property ownership (Schier/Hilti/Schad et al. 2015: 440). According to the rational choice theory, multi-local living thus helps combine the place-specific offers (Standortofferten) of several places to achieve a household's targeted lifestyle, as social, economic and cultural conditions are unequally distributed from a spatial perspective (Weichhart 2015: 387).

Spatial conditions therefore influence the decision to become or remain multi-local, while at the same time shaping the spatial-temporal organisation of such living arrangements. Simultaneously, multi-local living has spatial effects. On the one hand, old industrial or structurally weak rural regions, like parts of eastern Germany or southern Italy, tend to have higher unemployment. As a result, people migrate or decide to commute weekly or monthly to work in other regions, leading to the unequal utilisation of infrastructures and problems for civic engagement (Dittrich-Wesbuer/ Plöger 2013: 202; Greinke/Hilti 2020: 97-99). On the other hand, a high proportion of multi-local employees are to be found in international metropolises like London and Paris or in large cities with creative or knowledge-based jobs such as Stuttgart and Milan. Increased land consumption and traffic volumes - in addition to (long-distance) commuters - as well as tight housing markets and rising housing prices, usually in inner-city districts, are the result. Also, temporary population fluctuations lead to changes in retail offers and the greater use of infrastructures on specific days as well as to growth effects for household-oriented services (ARL 2016: 16; Kramer 2019: 294).

Multi-local living is facilitated by changing framework conditions. Better quality high-speed transport systems and information and communication technologies have both enabled and generated mobility and multi-locality. These technologies make it possible to reach people and places in less time or to maintain private and professional networks without being physically present (Urry 2004: 27). They also enable work itself to be shaped by temporal and spatial flexibility, with a shift away from standardised working hours and places (Pohl 2009: 358).

\subsection{Employers and multi-local living}

Even though there is a broad body of research on multilocal living, employer practices and the employees' perceptions of them are rarely examined. Literature on human resource management still focuses on employees living within daily commuting distance of their workplaces (Lee/Burch/ Mitchell 2014: 210; Holtbrügge 2015: 134; Kanning 2017: 157). Though generally overlooking whether employers are aware of the growing number of multi-local living arrangements, some studies give first hints of employers' (unconscious) influence and support. 
Employers can cause multi-local living through long probationary periods and fixed-term contracts, with employees deciding to not (yet) relocate their whole household for an insecure job (Greinke/Hilti 2020: 101). The creative and knowledge-based sectors in particular are shaped by projectbased work and thus multi-local living (Strambach/Kohl 2015: 265). Moreover, the recruitment radius plays an important role. It is being widened by demographical change and skills shortages at all levels in specific sectors such as engineering and information technology (Plöger 2020: 1742). For this reason, employers are increasingly recruiting workers whose centre of life is elsewhere and who decide to live in more than one place, thereby contributing to the spatial development of cities and regions.

To attract or retain workers, certain employers offer various material and immaterial benefits, including financial or time perks, training, insurance and benefits in kind (Holtbrügge 2015: 217). Even though these benefits are not solely devised for multi-local employees, it can be assumed that they make multi-local living easier (Meil/Ayuso/Mahia 2010: 318). Some companies even provide apartments or build company accommodation, thereby actively intervening in the housing market and spatial development of cities (Kadereit 2017: 279).

To exchange knowledge and keep up with the competition for resources and talents, cities, regions and especially companies are basing their activities on mobility, thus influencing the development of these areas. Kesselring and $\operatorname{Vogl}$ (2010: 79-92) address a normalisation of work-related mobility in various branches, with employers seeing it as an obvious consequence of globalisation, decentralisation and the need for proximity in several work areas. Working on the move or from home, also referred to as teleworking, is increasing as well (Felstead/Henseke 2017: 201), particularly for high-earners and employees in knowledgebased sectors (Meil/Ayuso/Mahia 2010: 321). In Germany, in 2014, at least 40 percent of all employees were able to work from home (Brenke 2016: 98), though just 12 percent occasionally did so in 2018 (Destatis 2019: 678). In Italy, just 5 percent of all employees worked from home in 2018, while in the whole of the European Union it was 15 percent (Destatis 2019: 678-679).

Intensive debates are currently taking place around the world among employers, politicians and scientists from several disciplines about how the Covid-19 pandemic has affected working from home and on the move (Demirbas/ Bozkurt/Yorgun 2020; Dingel/Neiman 2020; Reuschke/ Felstead 2020; Bonacini/Gallo/Scicchitano 2021). The German Socio-Economic Panel found out that 35 percent of all surveyed employees - especially high-earners - worked from home in spring 2020 due to the pandemic (Schröder/ Entringer/Göbel et al. 2020: 2).
Employer practices regarding multi-local living and employees' perceptions thereof should be further explored, as the literature review shows important research gaps. Questions arise as to what extent employees demand and receive employer support for their living arrangements, and how the practices influence the development of cities and regions. A further research focus is the extent to which employers still insist on rigid structures such as fixed working hours and places, thereby not supporting or even impeding such living arrangements. It is important to investigate these questions, as the number of multi-local employees is set to grow, thus shaping the spatial development of those areas highly affected. In the following, the paper provides initial answers to these questions.

\section{Methods and data basis}

To investigate the influence of employers on multi-local living from an employee point of view, an explorative-qualitative research design was chosen. The study uses semistructured problem-oriented interviews with multi-local employees in knowledge-based sectors, and does not claim to be representative. We chose knowledge-based sectors since professions such as engineering, research and academia are becoming increasingly mobile and multi-local (Bauder 2015: 85). An increased share of multi-local employees can be expected in large cities with internationally active companies, universities and research institutions. The study focuses on two such cities, Stuttgart in southwest Germany and Milan in northern Italy. Both are located in one of the most economically dynamic regions of their respective countries and feature above-average income levels, tight housing markets and high housing costs. At the same time, both offer shared or small (furnished) flats, hotels in different price segments as well as specific infrastructures such as household-oriented services, which the literature sees as necessary for multi-local living (ARL 2016: 16). Moreover, they feature good (inter)national car, train and plane connections and are thus easier to reach for e.g. (long-distance) commuters and multi-local employees. The research is built on two case studies, as these cities have highly contrasting labour markets, leading to the question of whether there are similarities in employee living and working conditions as well as the support required and received from employers.

The capital of the federal state of Baden-Württemberg, Stuttgart, is one of the biggest cities in Germany $(636,000$ inhabitants). It is known for its large international automotive and tech companies as well as research institutions and universities. Due to a high number of jobs in sectors such as engineering and research as well as demographic change, Stuttgart suffers from skills shortages, especially in 
academic fields (IHK Region Stuttgart 2019: 5-6). It can thus be expected that employers have specific policies to attract and retain employees from outside the region - and thus also multi-local employees.

Milan is the capital of the administrative region of Lombardy and the second largest city in Italy $(1,366,000$ inhabitants). The city is home to several major international automotive and financial companies as well as universities and is internationally known for its fashion industry. In contrast to Stuttgart, Italy and also Milan have a labour surplus, with over-skilling rampant especially among university graduates in science, technology and engineering (Monti/ Pellizzari 2017: 5). The question arises as to whether employees in Milan have the same support needs and perceive employer policies in the same way as employees in Stuttgart, despite the labour surplus and limited financial resources.

The sample was selected through the 'snowball' method, using posts in social media groups as well as the mailing lists of companies, academic networks and universities. Interviewees lived in Milan or Stuttgart for primarily work reasons and had a further residence in another region. To focus on employees whose private lives are affected by mobility, it was stipulated that the one-way travelling time between residences should be at least one hour with weekly or at least monthly commutes and a minimum of 60 nights per year spent in each residence (Limmer/Collet/Ruppenthal 2010: 19). As a further criterion, the respondents were required to work in knowledge-based sectors such as engineering, research and development or finance, as these sectors have a particularly high volume of multi-local employees and furthermore are key sectors in Stuttgart and Milan. The gender ratio was also to be balanced.

The semi-structured problem-oriented interviews (according to Helfferich 2011) lasted 60 to 120 minutes and covered topics such as residential and work location decisions as well as employers' influence on mobility, multilocality and the reconciliation of work and private life. All interviews were conducted by the author of this paper. Being about the same age as most of the interviewees, having the same education level and having herself lived multi-locally for several years, the interviewer was able to empathise with the interviewees. The interview atmosphere was trustful, with most interviewees talking in-depth about their private lives. The Stuttgart interviews were conducted in German, with any citations in this article translated into English by the author. The Milanese interviews were conducted in English and thus not in the interviewer's or interviewees' mother tongue. Even though all respondents spoke English fluently, sometimes it was a struggle to find the right words. This had to be taken into account during the analysis. All interviews were recorded and fully transcribed. The interviews were examined with qualitative content analysis (Mayring 2010) using the MAXQDA software.

The Stuttgart case study (fieldwork in 2018/2019) featured 24 interviews with graduate employees working mainly in research and development, academia or engineering. In Milan (fieldwork in 2019), 15 interviews were conducted with graduate employees mainly working in academia or finance. The Milanese case was balanced in terms of gender (8 to 7), while the Stuttgart case had a higher share of male respondents (16 to 8), in line with a German quantitative study in which 62 percent of the multi-local respondents were male (Dittrich-Wesbuer/ Kramer 2014: 50). Ages varied from 23 to 52, with a median age of 31 in Stuttgart and 27 in Milan. In Stuttgart, 21 respondents were in a relationship and two had children. In Milan, 11 respondents had a partner, none had children. Respondents from Stuttgart worked in large companies (10), research institutions or universities (9), while five worked in midsize companies. 15 had a permanent contract, nine a temporary one. The Milanese respondents worked in small (4), medium (3) and large companies (3) and universities (5). Eight had permanent and seven temporary contracts.

The analysis of the interviews was also based on certain types of multi-local living. We chose Hesse and Scheiner's (2007: 145-147) typology to categorise the interviewees as it is the most comprehensive typology of space-related types. The criteria of reasons for leading a multi-local life, travel periodicity and distance were already determined due to the selection criteria of the interviewees. As mentioned above, all respondents lived in Stuttgart or Milan for mainly work reasons, travelled between residences at least monthly and commuted at least one hour. In the analysis, the interviewees were categorised dependent on the criteria of further reasons for the multi-local life and hierarchy of the residences. The first type were shuttles, i.e. people living and working in Stuttgart or Milan with their main residence outside the region, i.e. there was a hierarchy of the residences. Further reasons for maintaining the main residence varied from family ties and other social contacts to specific facilities. The Stuttgart case study revealed 12 shuttles and Milan two. The second type were people in long-distance relationships with two separate households, the so-called living-apart-together. The main reason for multi-locality is the partner and there is no hierarchy of the residences, as both partners have their own household. Ten respondents in Stuttgart and seven in Milan lived as living-apart-together partners. The interviews revealed a third type: young multilocal employees, living in the city of their employer and at the same time at their parents' homes. The parents and other social contacts were the reasons for living multi-locally and 
there was no hierarchy of residences. The Stuttgart case revealed two and the Milanese case six young multi-local employees.

\section{Results}

Drawing on the empirical material, this section first provides insights into the perception of multi-local employees in knowledge-based sectors regarding their employers' policies for these living arrangements. The focus is on the extent to which multi-local employees demand and receive support and how employer practices and spatial development interact. The section goes on to list support requirements for different types of multi-local employees. It ends by explaining how employees deal with situations where their employers do not accept their living arrangements.

\subsection{Employer support for multi-local living arrangements}

The literature review revealed the research gap regarding employee perceptions of employer practices in support of multi-local living arrangements. The question arises as to which practices exist within companies. Furthermore, reasons why employers reject support for these arrangements have to be examined, as do differences between employer types and job types in knowledge-based sectors.

Looking at the question of how employers should or already do support multi-local living, respondents mentioned space-time work flexibility as the most important support, followed by financial benefits and benefits in kind. Respondents' experiences as well as the possible spatial effects of employer practices are analysed below.

\subsubsection{Space-time flexibility}

The interviews revealed that space-time work flexibility in the shape of flexitime, teleworking arrangements and considering commuting time as working time make it easier to live in more than one place and commute between residences. Flexitime allows people to start work later on Mondays or end earlier on Fridays, even allowing some respondents to commute to Stuttgart or Milan on Monday mornings instead of Sunday evenings. Moreover, teleworking agreements as well as the availability of ICT facilities such as laptops, mobile phones and network access allow more time to be spent at the remote residence. Most respondents had such facilities, enabling at least part of their work to be done remotely. However, there were also employees who were not allowed to do so, which to a far greater extent encouraged them to consider quitting their jobs.

Flexible space-time work arrangements can be formally enshrined in company collective agreements, employment contracts or addenda. In other cases, flexible arrangements are informally agreed between the employees and their superiors. Formal agreements were more the norm in Stuttgart than in Milan. In both cities, some respondents requested (greater) flexibility on their own initiative. Others received offers for flexible arrangements from the employer after a probationary period or right from the start. Working as an engineer for a big international company in Stuttgart, Raúl was able to work from home right from the start:

When I started looking for a new job, this was the only company which said straight away: "teleworking, of course!" In the very first interview, my current boss told me: "You can always pick a day for home office. If you need to, you can work from home for two or three days."

He decided to take up the job offer, because teleworking helped him spend longer periods at his main residence. The statement also shows that not all employers are willing to allow employees to work from home. The interviews suggest that the more specialised and irreplaceable an employee is and the greater the shortage of skilled workers in a company, the more likely employers are to be flexible in terms of space and time.

Nevertheless, there is a difference between employer types. The interviews suggest that employees working in universities and research institutions are more likely to have flexible work schedules and (in-)formal teleworking arrangements than those working in industry. Existing studies also associate universities and research institutes with flexible work and a great number of multi-local employees due to project-based work (Bauder 2015: 85; Petzold/Hilti 2015: 279). In both Stuttgart and Milan, the share of multilocal employees as well as flexible work arrangements also differs between locally rooted older companies and international companies recruiting from outside the region or country. Working for a start-up software development company in Milan which recruits all over Italy and beyond, Omar put it this way:

As long as you are doing your job, everything is extremely flexible. The moment my girlfriend moved to the UK, I told my superior: "I need to explore the limits of working remotely. We may explore the option where I work from UK for a month and come back for a month or so." And he was just like: "Yes, I think we can arrange whatever works for you."

Omar explained that his company was aware of the individual living situations of its employees and supported them as a staff retention measure. The literature also sees employers recruiting internationally as forerunners of flexibility (Mor- 
ris/Wright/Trevor et al. 2009: 986). By contrast, in both cities locally rooted older companies were less used to recruiting outside the region, and thus less aware of support needs for specific living arrangements. These employers often still stick to old attendance patterns and fixed working hours. Nevertheless, respondents from these companies explained that skills shortages were increasingly forcing their employers to widen their recruitment radius (also Plöger 2020: 1741).

Flexible work arrangements depend not only on specific employer types, but also on individual superiors. In both cities, in some companies working from home is allowed in certain departments and is forbidden in others, despite employees having the same working conditions like computerbased work and no client contact. Kai, an engineer in a big locally rooted company in Stuttgart, had this to say:

\section{There are bosses who say: "The work has to be done here and nowhere else and there is no discussion." And there are bosses, like mine, who say: "As long as you get your stuff done, do it as you like. Don't go telling everyone and maybe don't be gone all the time."}

This quotation shows that even if respondents are permitted to work from home, they are not always supposed to talk about it to avoid envy and frustration among their colleagues. This refers especially to the first employees in a department to negotiate work flexibility.

Reasons mentioned about why superiors forbid working from home include security problems due to sensitive data and maintaining the work environment. Phone and video calls were used in the minority of the respondents' departments to replace face-to-face meetings. However, we can assume that online meetings have currently (at least temporarily) increased in most respondents' companies due to the Covid-19 pandemic. Some superiors had had negative experiences with home office arrangements, being unsatisfied with work results or annoyed about not being able to easily contact employees at home. Moreover, a superior's lack of interest in individual living situations was cited as a reason for a lack of work flexibility. It can be assumed that such companies (still) have few problems in recruiting appropriate employees, meaning that they do not have to think about the specific living arrangements and support requirements of (future) employees. Nevertheless, most respondents in both cities believed that their employers would expand work flexibility in the future as it can contribute to employer attractiveness and reduce staff turnover (also Felstead/Henseke 2017: 208).

\subsubsection{Financial benefits and benefits in kind}

Further possibilities for employers to support multi-local lives include financial compensation for transport or hous- ing expenditures. The benefits in the respondents' companies varied from subsidised train tickets, fuel or car insurance up to the full reimbursement of train tickets, cars or hotel rooms. These benefits are for the most part individually negotiated between the employee and the superior. The length of time spent in the company plays only a minor role, in contrast to work experience, with some employees explaining that their employers tried to attract experts by offering them financial support right from the beginning. Our analysis revealed that financial support was more likely in Stuttgart than in Milan, with Milanese respondents considering the lack of their companies' resources to be the main reason.

Only few respondents see their employers - mainly larger ones - as being in a position to provide financial support. In Stuttgart, some (high-skilled) employees were even provided with hotel rooms. Working for a big international company, 38-year-old engineer Bernd slept in a hotel for the three days spent each week in Stuttgart:

\section{I am glad to get the Bahncard-50, meaning that I only pay half of my train tickets. And I can choose a hotel up to a maximum of 100 euros per night, with my employer paying for it.}

On first relocating to Stuttgart or Milan, most respondents looked for centrally located smaller or shared apartments. Due to the tight housing markets in both cities, nearly all respondents had difficulties finding an appropriate flat at the beginning of their stay and some decided to first rent temporary accommodation or to sleep at a friend's house. No employer in either Stuttgart or Milan had company apartments. But most interviewees talked about informal help in finding a flat, such as colleagues asking acquaintances about available apartments. One employer in Stuttgart and one in Milan provided furnished apartments for a few months until new employees found their own flats. These were private companies recruiting nationwide and beyond, endowed with sufficient financial resources and, as mentioned above, more aware of specific living situations.

\subsubsection{Spatial impacts of employer support}

The analysis revealed that employer practices on multi-locality and spatial conditions influence each other. On the positive side, employers attract people who would not normally live in these cities, i.e. respondents lived in Stuttgart or Milan mainly for work reasons. This influx of highly qualified employees strengthens the knowledge intensity of the regional economies, while the additional purchasing power is a boost to retail sectors in Stuttgart and Milan, at the further residence and in between. On the negative side, respondents' prolonged flat searches indicate that multi-local employees can put further pressure on housing markets, 
possibly even displacing existing population groups focused on the same housing segment (e.g. small-sized flats). However, this effect is eliminated when companies pay for hotel rooms.

Besides, spatial infrastructures in both cities facilitate life in and between the residences. For instance, respondents were able to make use of (inter)national train, car and plane connections. Appropriate employer support can further facilitate commuting: employees in Stuttgart who travelled a lot, e.g. visiting clients or doing on-site research, often had company cars or rail cards paid for by their employers and could use them for travelling to the other residence. An employer's sector plays a role in terms of support: respondents working for automotive companies received less support for public transport but were able to lease or buy company cars at a discount. Thus, employers' actions can influence the means of transport used for commuting.

As a negative spatial effect, multi-locality can further swell traffic volumes and the use of long-distance public transport, especially on Mondays and Fridays (ARL 2016: 16). However, employer practices can soften these effects: flexible work can reduce traffic volumes and relieve public transport systems, with several respondents stating that they commuted on days other than Mondays or Fridays. For employers, telework can help reduce office space and costs, with interviewees stating that they had no assigned desk or shared a desk with other employees. This reduces office space requirements, subsequently leading to less land consumption or freeing up space for other uses such as housing.

The interviews revealed a further consequence of flexible work: in addition to personal attitudes favouring social involvement at their places of residence (Petzold 2013: 394), respondents allowed to work at their main residence were less able and willing to socialise after work and made less use of leisure facilities in Stuttgart or Milan due to financial restrictions. For example, one interviewee stated that she would have liked to join a fitness studio, but that it "is not worth it if I can't use the membership from Thursday to Monday". Others cited time restrictions due to high workloads when they were in Stuttgart or Milan for just a few days per week, as one explained: "When I'm here, I'm often working until late in the evening, so it's pointless to think about evening activities." Social cohesion in neighbourhoods with a large number of multi-local employees may suffer if people only stay there a few days a week or month.

\subsection{Types of multi-local employees and their support requirements}

As mentioned above, the analysis of the interviews reveals different types of multi-local employees. The question arises as to whether multi-local employees require the same support from their employers and whether there are parallels between the employee support demanded and received in Stuttgart and Milan.

\subsubsection{Shuttles}

Shuttles lived and worked in Stuttgart or Milan, yet had their main residence outside the region, mostly with their partners or families. Commuting frequency and the duration of stays at the residences varied in line with distance and work flexibility (Hesse/Scheiner 2007: 145). In our study, respondents tended to commute every week. The Stuttgart case revealed 12 shuttles, 11 of whom were in a relationship and two of whom had children. The Milan case revealed two shuttles, both in a relationship without children. Aged between 30 and 52, shuttles were older than the following two types and thus had more work experience. Shuttles in both cities considered employer support for their living arrangements to be crucial, because their centre of life was elsewhere and they were the only person in their household commuting between the residences. Respondents with fixed hours and workplaces felt constraints on their worklife balance.

The two Milanese shuttles spoke of a lack of job opportunities near their main residence in southern Italy or rural areas, which meant they felt pressured to stay in Milan. They lived multi-locally in their attempt to combine the social and natural environment of their main residence and the job opportunities in Milan. Both were well aware of the labour surplus in Milan and were afraid of losing their jobs, stating that they were easily replaceable. Therefore, they accepted a lack of support for their living arrangements and were reticent about demanding support.

All 12 Stuttgart shuttles had space-time flexibility at work and most were allowed to work at their main residence for several days a week. Some even got financial support such as subsidised train tickets or hotel rooms. These were older shuttles with more work experience and probably better negotiating skills than younger colleagues. Most could imagine living multi-locally for a long time, as they enjoyed their work and the support. Shuttles from structurally weak areas in Germany also faced problems finding jobs near their main residence, viewing their living arrangements as a chance to combine a good job and the preferred main residence. Most were not afraid of losing their jobs, underlining the skills shortage in knowledge-based sectors in Stuttgart.

Regarding infrastructure use, shuttles were less likely to take part in leisure activities, with these mostly limited to occasional meetings with colleagues. They worked as much as possible when staying in Stuttgart or Milan in an attempt to have more free time at their main residence, especially for shuttles in a relationship and with children. 


\subsubsection{Living apart together}

The second type is living-apart-together (LAT-partners), couples in a long-distance relationship with two separate residences. One partner lived and worked in Stuttgart or Milan, while the other lived outside the region. The partners took turns to commute, mostly on a weekly or fortnightly basis. The Stuttgart case comprised ten LAT-partners, the Milanese case seven. All were 33 or younger, and viewed the living arrangements as temporary, seeking to live together as soon as they started a family. The literature suggests that this type of relationship is particularly common among young adults and is usually only maintained for a few years to reconcile partnership and (first) employment (Asendorpf 2008: 761-762). LAT-partners mostly did not consider employer support to be as necessary as shuttles, because they took turns with commuting and thus commuted less. LATpartners in need of (more) support were mostly too afraid to request it, particularly at the beginning of their careers.

The Milanese respondents - especially the ones from southern Italy or living in rural areas - spoke of their huge difficulties in finding an appropriate job near their partner's residence. Most LAT-partners believed that northern Italy and particularly Milan offered better job opportunities, which meant they intended to live together with their partner in Milan in the future. But the partners' attachment to their current residences or to their workplaces inhibited the partners from relocating to Milan (yet).

Similarly in Stuttgart, several respondents spoke of their difficulties in finding a job near their partner due to a lack of jobs in their profession. But for the most part, attachment to the employer, to the job itself or to Stuttgart was a reason to not (yet) look for a job near the partner's residence. On the other hand, the respondents' partners did not want to relocate to Stuttgart (yet), due to their attachment to their current jobs or places of residence or because of a lack of jobs in the - engineering-dominated - Stuttgart labour market.

For LAT-partners, finding an appropriate, centrally located residence was more important than for shuttles, as their main residence was in Stuttgart or Milan. All LATpartners were interested in using leisure facilities like sports clubs or music schools and building social networks extending beyond colleagues. Some even engaged in voluntary work like tutoring or animal aid. These activities tended to take place during the week, with weekends reserved for visits from or to the partner.

\subsubsection{Young multi-local employees}

The analysis revealed a third type often overlooked in recent studies: young multi-local employees. Living and working in Stuttgart or Milan, they had a room at their parents' home where they slept every second or third weekend. Reasons for sleeping at the parents' homes included family, friends and specific facilities such as sports clubs. Two respondents in Stuttgart and six in Milan belonged to this type. Aged 29 or less, they were younger than the shuttles and LATpartners studied. None of the young multi-local employees had requested (more) flexibility at work, as they were at the beginning of their careers and felt too inexperienced. Besides, most of them did not see it as their employers' task to support their multi-local life.

In contrast to shuttles, most young multi-local employees saw the centres of their lives not just in one place, but in two. There is rather a co-existence of two important residences (Hilti 2013: 112), allowing them to combine working and living in Stuttgart or Milan with access to the place where they grew up. One interviewee put it this way: "I see myself in both places. I know what I miss when I'm here, but I also know what I miss when I'm there." Most respondents did not yet know whether they wanted to move back to their hometowns in the future. Those who had grown up in structurally weak or rural areas in Germany or Italy believed that they would probably never go back to their hometowns, insofar as they wanted to keep a good job.

All young multi-local employees made use of leisure facilities and built social networks in Stuttgart or Milan. At the same time, the respondents maintained strong social networks in their hometowns, with social contacts, leisure and voluntary activities being the main reasons for maintaining these residences.

\subsection{How employees deal with an employer's lack of acceptance}

Our analysis of the interviews revealed that some employees faced a lack of acceptance at work regarding their multilocal life. This section looks at how employees deal with this lack of acceptance, focusing on shuttles as they tend to commute more often than the other types and have higher support requirements.

\subsubsection{Employees quit their jobs}

The literature shows that multi-local employees tend to terminate their jobs when their contracts expire. Others quit due to dissatisfaction with the job itself, due to the financial burdens of their living arrangements or to live with a partner or family (Asendorpf 2008: 761; Lück/Ruppenthal 2010: 51). Our study reveals that a lack of acceptance at work for their living arrangements can also be a reason to quit. Shuttles, in particular those with strict working hours and places, tend to resign when they find a job offering better working conditions or a similarly good job close to their main residence.

In particular, employees on permanent contracts face 
a lack of acceptance for their multi-local lives. The interviews indicated that certain employers still think that permanent contracts and their supposed (e.g. financial) security encourage employees to relocate to their places of work. They seem not to understand that attachment to other places due to social contacts, regional preferences as well as a partner's job can be an obstacle to relocating. As an example, 30 -year-old project manager Inga had a temporary contract in Stuttgart for one year. During that time her employer accepted her multi-local living and even paid for her to commute to her main residence. On receiving a permanent contract, the financial support was stopped. Her superior and colleagues could not imagine why she refused to relocate to Stuttgart. She had this to say:

For twelve months they paid two home trips every month. After that it was stopped, because the expectation was: "Well, you can move your centre of life to Stuttgart."

Some respondents even decided to quit on account of the lack of support. It was not just the financial burden or the temporary absence from their families and friends, but also the lack of acceptance which made them resign upon finding a new job elsewhere.

\subsubsection{Employees tolerate their jobs}

Quitting is not an option for employees with specialised professions who are unable to easily find a job elsewhere. Moreover, tight labour markets make it difficult to find another job. Both the Milanese respondents and those from Stuttgart who had their other residences in structurally weak regions did their best to hold on to their jobs, even though the lack of acceptance and support made them feel bad at work. Francesco, a graphic designer in Milan, stated that his employer forbade working from home and ignored his requests to leave work earlier:

When I ask to have the Friday afternoon off to go home, it's always a problem. You are asking too much. They would like you to just take time off in the summer when you go on holiday. At all other times, they want you to stay in the office - if possible, every day and every hour and every week.

This quotation suggests the employer wants to keep the work environment within the company. With many colleagues being fired due to financial problems in the company, Francesco wanted to avoid getting dismissed as well. Because of difficulties finding another good job in Milan or near his main residence, he tolerated his job and the associated working conditions. Employers can afford to refuse support when employees are unable to find another job due to tight labour markets and can easily be replaced. The Mi- lanese respondents felt themselves more easily replaceable than their Stuttgart counterparts.

\subsubsection{Employees accept a downgraded contract}

Some respondents stated that their very jobs may be undermined by a superior who knows that the main residence is elsewhere. For example, Stefanie worked for a large company in Stuttgart and tried to negotiate working sometimes at her main residence in Cologne. Turning down her request, the superior even undermined her job:

My contract, which was secure, became a temporary contract, because my boss believes that I do not really want the job and that it might not be the right one for me if my heart is set on Cologne so much.

Stefanie accepted the temporary contract to avoid further fights with her superior, making her feel bad at work. Her superior thought that she was about to quit her job to get back to Cologne. He preferred having a fixed end date for her contract, allowing him to better plan for new employees. It can be assumed that such employers or rather such departments have few difficulties in finding new employees.

\subsubsection{Employees conceal their living arrangements}

Some employees concealed their multi-local life to avoid negative consequences for their current job or their career prospects. Our analysis revealed that shuttles, much more than LAT-partners or young multi-local employees, either consciously spoke openly about their living arrangements at work with a view to negotiating support or consciously concealed them.

Shuttles who wanted to relocate to their main residences due to specific pressures but had problems finding a job there were particularly prone to concealing their living situations. In particular, respondents wanting to start a family or care for elderly parents felt pressure to leave Stuttgart or Milan.

Employees on permanent contracts consciously concealed their living arrangements so that their employers would not think that they were less motivated and focused due to commuting between the residences. Furthermore, the respondents wanted to hide their intention to quit once they had found an appropriate job near their main residence. Working in Stuttgart, 31-year-old Esther wanted to relocate to her main residence to start a family, but jobs in her specialised profession were not easy to find there. She consciously did not tell her boss where her main residence was, because she was afraid of negative consequences like losing out on good assignments and thus getting less satisfaction from work:

What matters most to me is that I do not tell my boss 
where I live [...] I'm afraid that the good projects will no longer be assigned to me [...] If they know I live there, they'll probably think I'll be gone soon. I don't want to give this impression, even though they may be right.

At the same time, she felt no need to request support, as home office arrangements and flexitime made her living situation easier, with her superior unconsciously supporting her living arrangements.

For employees on temporary contracts, concealing a multi-local situation while at work can be a strategy when they are afraid of not getting a follow-on contract. 35-year-old Lorenzo worked as a researcher in Milan and had his main residence in southern Italy where it was difficult to find work. On starting work in Milan, his boss wanted him to relocate. Even though Lorenzo was allowed to work from home he wanted to be seen at work, displaying productivity and doing everything to stick in his superiors' minds to get future contracts:

\section{They asked me several times about my intention to rent an apartment in Milan [...] If there is an opening af- ter my postdoc and they think I want to move back, they won't offer me that opportunity, because they'll be saying: "He doesn't want to stay in Milan. We'll sup- port another researcher." It's not an easy situation. If I show that my family, my affection, lie [elsewhere], this can affect the openings that I get after my postdoc. So I have to manage the situation carefully. It's really complicated.}

Even though he liked his job, he would prefer to work in his hometown. It became clear that his superior wanted employees who worked well and would not suddenly leave the department. The respondents were aware that their superiors' fear was justified: if they got the right job they would move to their main residence straight away. Moreover, the interviews made it clear that the job situation in specific fields was difficult in Milan. Respondents were afraid that negative impressions could lead to an employee being 'replaced'. Nevertheless, they were able to consciously conceal their living situations, not being forced to communicate at work that their main residence was elsewhere.

\section{Conclusion and further research}

Changing structural conditions in labour markets and society are leading to an increasing number of employees with multi-local living arrangements in several sectors, in particular knowledge-based ones. Attracting and retaining employees from outside the region has a key role to play in the competition for resources and talents. To achieve a good work-life balance for their multi-local employees, employers play a specific role in supporting or impeding their employees' living arrangements. Nevertheless, studies of multi-local living rarely focus on employer practices and employees' perception of them. This paper does just that, focusing on multi-local employees in knowledge-based sectors and the associated employer practices.

Our analysis reveals that especially space-time flexibility, financial support and benefits in kind could ease the spatialtemporal organisation of multi-local living. In Stuttgart and Milan, the same types of multi-local employees had the same support requirements, with shuttles calling for more employer support than LAT-partners and - in this study for the first time identified as an important, separate type young multi-local employees. Concerning support received, financial support was less likely in the Milanese case due to employers lacking the necessary financial resources. Spacetime flexibility differed between employer types, with research institutions, universities and international companies in both cities more open to it than local companies. At an individual level, employees filling important vacancies or with more work experience tended to get more support.

Nevertheless, the analysis provides first hints that employers in Stuttgart and Milan apparently have no corporate policies on multi-local living and that it remains up to superiors' individual attitudes as well as employees' individual negotiation capacities as to whether or not these arrangements are tolerated and/or encouraged. When superiors do not accept employees' living arrangements, employees have different ways to respond. Tolerating the situation is necessary when employees have fewer job opportunities due to specific professions or labour surpluses. This was more the case for Milanese respondents due to the labour surplus in Milan as well as a lack of job opportunities in southern Italy and rural areas, but also for employees in Stuttgart whose main residence was in a structurally weak region. Consciously concealing such living arrangements is a further possible strategy for employees afraid of negative consequences for current or future employment. When general support policies, such as teleworking arrangements, are already available, employers unconsciously support multilocal living.

Employers, and also cities and regions concerned about their (inter)national position, need to deal more consciously and intensively with multi-local living and take it into account in their development strategies and actions. In this context, attention should be directed not only to the greater support required from employers or additional pressure on (tight) housing markets and the unbalanced use of infrastructures on the part of the cities concerned. Multi-local living also offers opportunities, such as attracting high-skilled 
workers or boosting a city's overall knowledge intensity, purchasing power and diversification (Dittrich-Wesbuer/Plöger 2013: 202). We should therefore view employees not just as workers, but as users of housing and leisure facilities and as drivers of a city's economy, taking account of their diverse living situations in an effort to derive maximum mutual benefit for all - employees, employers, cities and regions. This sample and discussion of the types of multi-local employees in Stuttgart and Milan provides first hints of multilocals' living situations and support requirements. Nevertheless, future studies should further explore these types as well as employees in different living situations (such as with children) and in different sectors, allowing the different support requirements to be considered. Besides, further spatial effects of multi-local living in different spatial contexts should be examined and there is a need to talk directly to employers and city and regional administrations to investigate their perspectives.

Finally, it should be noted that this study was conducted before the Covid-19 pandemic. Research is needed on how the temporary expansion of home-based work and the substitution of face-to-face meetings by phone and video meetings will influence employer and employee acceptance of working from home and how telework and travel restrictions are changing the organisation of multi-local living arrangements. Furthermore, it will be interesting to examine the spatial effects of the Covid-19 pandemic.

\section{References}

ARL - Akademie für Raumforschung und Landesplanung (2016): Multilokale Lebensführung und räumliche Entwicklungen. Hannover. = Positionspapier aus der ARL 104.

Asendorpf, J.B. (2008): Living apart Together. Alters- und Kohortenabhängigkeit einer heterogenen Lebensform. In: Kölner Zeitschrift für Soziologie und Sozialpsychologie 60, 4, 749-764. https://doi.org/10.1007/s11577-0080035-4

Bauder, H. (2015): The International Mobility of Academics. A Labour Market Perspective. In: International Migration 53, 1, 83-96. https://doi.org/10.1111/j.14682435.2012.00783.x

Boltanski, L.; Chiapello, E. (2007): The New Spirit of Capitalism. London.

Bonacini, L.; Gallo, G.; Scicchitano, S. (2021): Working from home and income inequality. Risks for a 'new normal' with COVID-19. In: Journal of Population Economics 34, 1, 303-360. https://doi.org/10.1007/s00148020-00800-7

Brenke, K. (2016): Home Office. Möglichkeiten werden bei weitem nicht ausgeschöpft. In: DIW-Wochenbericht 83, 5, 95-105.

Brickell, K.; Datta, A. (2011): Translocal Geographies. Spaces, Places, Connections. Farnham.

Christopherson, S.; Michie, J.; Tyler, P. (2010): Regional resilience. Theoretical and empirical perspectives. In: Cambridge Journal of Regions, Economy and Society 3, 1, 3-10. https://doi.org/10.1093/cjres/rsq004

Demirbas, D.; Bozkurt, V.; Yorgun, S. (eds.) (2020): The Covid-19 Pandemic and Its Economic, Social, and Political Impacts. Istanbul. https://doi.org/10.26650/B/SS46. 2020.006

Destatis - Statistisches Bundesamt (2019): Statistisches Jahrbuch 2019. Deutschland und Internationales. Wiesbaden.

Dingel, J.I.; Neiman, B. (2020): How many jobs can be done from home? In: Journal of Public Economics 189, 104235. https://doi.org/10.1016/j.jpubeco.2020.104235

Dittrich-Wesbuer, A.; Kramer, C. (2014): Heute hier - morgen dort: Residenzielle Multilokalität in Deutschland. In: Geographische Rundschau 11, 46-53.

Dittrich-Wesbuer, A.; Plöger, J. (2013): Multilokalität und Transnationalität. Neue Herausforderungen für Stadtentwicklung und Stadtpolitik. In: Raumforschung und Raumordnung 71, 3, 195-205. https://doi.org/10.1007/ s13147-013-0237-8

Duchêne-Lacroix, C.; Ködel, S. (2020): Geschichtliche Betrachtung multilokaler Wohnformen. In: Danielzyk, R.; Dittrich-Wesbuer, A.; Hilti, N.; Tippel, C. (eds.): Multilokale Lebensführungen und räumliche Entwicklung. Ein Kompendium. Hannover, 133-139 = Forschungsberichte der ARL 13.

Elliott, A.; Urry, J. (2010): Mobile Lives. London.

Felstead, A.; Henseke, G. (2017): Assessing the growth of remote working and its consequences for effort, wellbeing and work-life balance. In: New Technology, Work and Employment 32, 3, 195-212. https://doi.org/10. 1111/ntwe.12097

Gehrke, B.; Rammer, C.; Frietsch, R.; Neuhäusler, P. (2010): Listen wissens- und technologieintensiver Güter und Wirtschaftszweige. Zwischenbericht zu den NIW/ ISI/ZEW-Listen 2010/2011. Hannover. = Studien zum deutschen Innovationssystem 19-2010.

Greinke, L.; Hilti, N. (2020): Temporär genutzte Räume von berufsbedingt multilokal Lebenden. Herausforderungen und Potenziale für betriebliche und regionale Entwicklungen in ländlichen Räumen Niedersachsens. In: Raumforschung und Raumordnung | Spatial Research and Planning 78, 1, 89-105. https://doi.org/10.2478/rara-20190045

Hansen, H.K.; Niedomysl, T. (2009): Migration of the creative class. Evidence from Sweden. In: Journal of 
Economic Geography 9, 2, 191-206. https://doi.org/10. 1093/jeg/lbn046

Helfferich, C. (2011): Die Qualität qualitativer Daten. Manual für die Durchführung qualitativer Interviews. Wiesbaden. https://doi.org/10.1007/978-3-531-92076-4

Hesse, M.; Scheiner, J. (2007): Räumliche Mobilität im Kontext des sozialen Wandels. Eine Typologie multilokalen Wohnens. In: Geographische Zeitschrift 95, 3, 138-154.

Hilti, N. (2013): Lebenswelten multilokal Wohnender. Eine Betrachtung des Spannungsfeldes von Bewegung und Verankerung. Wiesbaden. = Stadt, Raum und Gesellschaft 25. https://doi.org/10.1007/978-3-65801046-1

Holtbrügge, D. (2015): Personalmanagement. Berlin. https:// doi.org/10.1007/978-3-662-48110-3

IHK - Industrie- und Handelskammer Region Stuttgart (2019): IHK-Fachkräftemonitoring bis 2030. Steigender Fachkräftemangel kostet Milliarden. Stuttgart.

Kadereit, P. (2017): Werkswohnungsbau als wiederentdeckte Aufgabe. In: Albers, H.-H.; Hartenstein, F. (eds.): CSR und Stadtentwicklung. Unternehmen als Partner für eine nachhaltige Stadtentwicklung. Berlin, 279-296. https://doi.org/10.1007/978-3-662-50313-3_16

Kaltenbach, M. (2020): Die räumliche Dimension residenzieller Multilokalität. Eine Untersuchung beruflich induzierter städtischer Nebenwohnsitze und ihrer städtebaulichen Relevanz. Dissertation am Karlsruher Institut für Technologie. https://doi.org/10.5445/IR/1000122543

Kanning, U.P. (2017): Personalmarketing, Employer Branding und Mitarbeiterbindung. Forschungsbefunde und Praxistipps aus der Personalpsychologie. Berlin. https:// doi.org/10.1007/978-3-662-50375-1

Kaufmann, V. (2002): Re-thinking Mobility. Aldershot.

Kesselring, S.; Vogl, G. (2010): Betriebliche Mobilitätsregime. Die sozialen Kosten mobiler Arbeit. Berlin. = Forschung aus der Hans-Böckler-Stiftung 117

Kramer, C. (2019): Studierende im städtischen Quartier. Zeit-räumliche Wirkungen von temporären Bewohnern und Bewohnerinnen. In: Henckel, D.; Kramer, C. (eds.): Zeitgerechte Stadt. Konzepte und Perspektiven für die Planungspraxis. Hannover, 281-310. = Forschungsberichte der ARL 9.

Lee, T.W.; Burch, T.C.; Mitchell, T.R. (2014): The Story of Why We Stay. A Review of Job Embeddedness. In: Annual Review of Organizational Psychology and Organizational Behavior 1, 199-216. https://doi.org/10.1146/ annurev-orgpsych-031413-091244

Limmer, R.; Collet, B.; Ruppenthal, S. (2010): Introduction. Job-Related Spatial Mobility in Contemporary European Societies. In: Schneider, N.F.; Collet, B. (eds.): Mobile Living Across Europe II. Causes and Consequences of
Job-Related Spatial Mobility in Cross-National Comparison. Opladen, 15-24.

Löw, M. (2001): Raumsoziologie. Frankfurt am Main.

Lück, D.; Ruppenthal, S. (2010): Insights into Mobile Living. Spread, Appearances and Characteristics. In: Schneider, N.F.; Collet, B. (eds.): Mobile Living Across Europe II. Causes and Consequences of Job-Related Spatial Mobility in Cross-National Comparison. Opladen, 37-68.

Mayring, P. (2010): Qualitative Inhaltsanalyse. Grundlagen und Techniken. Weinheim.

Meil, G.; Ayuso, L.; Mahia, R. (2010): Support for Job Mobile People and Their Adaption to Mobility. In: Schneider, N.F.; Collet, B. (eds.): Mobile Living Across Europe II. Causes and Consequences of Job-Related Spatial Mobility in Cross-National Comparison. Opladen, 317-336.

Mills, M.; van de Bunt, G.G.; de Bruijn, J. (2006): Comparative Research: Persistent Problems and Promising Solutions. In: International Sociology 21, 5, 619-631. https://doi.org/10.1177/0268580906067833

Montanari, G. (2016): Großeltern erzählen geographisch von ihrer Familie. Zur Bedeutung von Raumsemantiken für die Konstitution kommunikativ vermittelter Sinnwelten. Dissertation am Karlsruher Institut für Technologie. https://doi.org/10.5445/IR/1000055133

Monti, P.; Pellizzari, M. (2017): Skill Mismatch and Labour Shortages in the Italian Labour Market. Milan. = Innocenzo Gasparini Institute for Economic Research Policy Brief 02.

Morris, S.; Wright, P.; Trevor, J.; Stiles, P.; Stahl, G.; Snell, S.; Paauwe, J.; Farndale, E. (2009): Global challenges to replicating HR. The role of people, processes, and systems. In: Human Resource Management 48, 6, 973-995. https://doi.org/10.1002/hrm.20325

Nadler, R. (2014): Plug \& Play Places. Lifeworlds of Multilocal Creative Knowledge Workers. Warsaw.

Ojala S.; Pyöriä, P. (2018): Mobile knowledge workers and traditional mobile workers. Assessing the prevalence of multi-locational work in Europe. In: Acta Sociologica 61, 4, 402-418. https://doi.org/10.1177/0001699317722593

Petzold, K. (2013): Multilokalität als Handlungssituation. Lokale Identifikation, Kosmopolitismus und ortsbezogenes Handeln unter Mobilitätsbedingungen. Wiesbaden. https://doi.org/10.1007/978-3-531-19490-5

Petzold, K.; Hilti, N. (2015): Intentionen zur Multilokalisierung bei Akademikerinnen und Akademikern. Biografische Erfahrungen als „Eisbrecher“. In: Scheiner, J.; HolzRau, C. (eds.): Räumliche Mobilität und Lebenslauf. Studien zur Mobilitätsbiografien und Mobilitätssozialisation. Wiesbaden, 277-295. https://doi.org/10.1007/9783-658-07546-0_15

Plöger, J. (2020): Employers stuck in place? Knowledge sector recruitment between regional embedded- 
ness and internationalization. In: Regional Studies 54, 12, 1737-1747. https://doi.org/10.1080/00343404.2020. 1765231

Pohl, T. (2009): Entgrenzte Stadt. Räumliche Fragmentierung und zeitliche Flexibilisierung in der Spätmoderne. Bielefeld.

Reuschke, D. (2010): Multilokales Wohnen. Raum-zeitliche Muster multilokaler Wohnarrangements von Shuttles und Personen in einer Fernbeziehung. Wiesbaden. https://doi. org/10.1007/978-3-531-92283-6

Reuschke, D.; Felstead, A. (2020): Changing workplace geographies in the COVID-19 crisis. In: Dialogues in $\mathrm{Hu}-$ man Geography, 10, 2, 208-212. https://doi.org/10.1177/ 2043820620934249

Rüger, H.; Ruppenthal, S. (2010): Advantages and Disadvantages of Job-Related Spatial Mobility. In: Schneider, N.F.; Collet, B. (eds.): Mobile Living across Europe II: Causes and Consequences of Job-Related Spatial Mobility in Cross-National Comparison. Opladen, 69-94.

Schier, M. (2009): Räumliche Entgrenzung von Arbeit und Familie. Die Herstellung von Familie unter Bedingungen von Multilokalität. In: Informationen zur Raumentwicklung 1/2, 55-66.

Schier, M.; Hilti, N.; Schad, H.; Tippel, C.; Dittrich-Wesbuer, A.; Monz, A. (2015): Residential Multi-Locality Studies. The Added Value for Research on Families and Second Homes. In: Tijdschrift voor Economische en Sociale Geografie 106, 4, 439-452. https://doi.org/10.1111/ tesg. 12155

Schröder, C.; Entringer, T.; Göbel, J.; Grabka, M.; Graeber, D.; Kröger, H.; Kroh, M.; Kühne, S.; Liebig, S.;
Schupp, J.; Seebauer, J.; Zinn, S. (2020): Vor dem Covid19-Virus sind nicht alle Erwerbstätigen gleich. Berlin. = DIW aktuell 41.

Sheller, M.; Urry, J. (2006): The new mobilities paradigm. In: Environment and Planning A 38, 2, 207-226. https:// doi.org/10.1068/a37268

Strambach, S.; Kohl, H. (2015): Mobilitätsdynamiken und Wissensarbeit. Zum Wandel berufsbedingter zirkulärer Mobilität. In: Raumforschung und Raumordnung 73, 4, 257-268. https://doi.org/10.1007/s13147-015-0355-6

Tippel, C.; Plöger, J.; Becker, A. (2017): 'I don't care about the city'. The role of connections in job-related mobility decisions of skilled professionals. In: Regional Studies, Regional Science 4, 1, 94-108. https://doi.org/10.1080/ 21681376.2017.1315611

Urry, J. (2004): Connections. In: Environment and Planning D 22, 1, 27-37. https://doi.org/10.1068/d322t

Weichhart, P. (2015): Residential multi-locality. In search of theoretical frameworks. In: Tijdschrift voor Economische en Sociale Geografie 106, 4, 378-391. https://doi.org/10. 1111/tesg. 12156

Weiske, C.; Petzold, K.; Zierold, D. (2009): Multilokale Haushaltstypen. Bericht aus dem DFG-Projekt „Neue multilokale Haushaltstypen“ (2006-2008). In: Informationen zur Raumentwicklung 1/2, 67-75.

Williams, S.; Bradley, H.; Devadason, R.; Erickson, M. (2013): Globalization and Work. Cambridge.

Zenker, S.; Eggers, F.; Farsky, M. (2013). Putting a price tag on cities: Insights into the competitive environment of places. In: Cities 30, 133-139. https://doi.org/10.1016/j. cities.2012.02.002 